Health Organization a new internationel agency for research into cancer, to co-ordinate national efforts and provide any service likely to be of international value. Finally, he pointed out that the balance of argument in recent years soemed to have shifted in favour of public education in this problom, and in 1963 the Ministry of Health encouraged certain larger local authorities to initisto local schemes of education in connexion. with cancer. The largest, in South Lancashire and Cheshire, covered an area of about 2.5 million peoplo and the results indicated that the time was ripe for a national effort. This was being studied in tho Ministry of Health by the Standing Advisory Committee.

\title{
The International Primatological Society
}

Ar the opening of tho Delta Regional Primate Research Conter noar Covington, Louisiana, its director, Dr. A. Riopelle, had invitod a number of primatologists. At this mooting an 'International Primatological Society' was founded, which is dedicated to tho advancoment and co-ordination of primatological research in its broadost aspocts, including medical applications. Special emphasis is placed on the intensification of exchanges of viows. Officors elected were: President, Dr. L. Carmichael, Washington, D.C.; Vice-presidents, Prof. D. Starck, Frankfurt.a.M, Germany, and Prof. Vandebroeck, Louvain, Belgium; Secrelary General, Prof. H. Hofer, Frankfurt a.M., Gormany; Secretary for Western Hemisphere, Dr. C. R. Carponter, Chapel Hill, N.C.; Secretary for Eastern Asia, Dr. K. Imanishi, Kyoto, Japan ; Secretary for Europe, Dr. H. Preuschoft, Tübingen, Gormany; Treasurer, Dr. H. Sprankel, Frankfurt a.M., Germany; The Society headquarters is to be located at Frankfurt a.M., where tho next meting will be held. So long as no poriodical is published, the membership fee will be 2 U.S. dollars per annum (payablo to the order of Dr. Sprankel, treasurer). Further information concerning membership can be obtained from Dr. H. Sprankel, Max Planck-Institut für Hirnforschung, Doutschordonsstrasse 43, Frankfurt a.M., Gormany.

\section{Veterinary Non-proprietary Names}

The British Veterinary Codex Revision Committee has adopted the following non-propriotary names for the veterinary substances indicated:

Non-proprietary

Bunamidine

Crufomate

Dimpylate

Haloxon

Pyrithidium bromide 3 -amino-8-(2-amino-6-methylpyrimidin-4-ylamino)-

$\checkmark N$-dibutyl-4-hexyloxy-1-naphthamidine; Scolaban

2-chloro-4-t-butylphenyl methyl $N$-methylphosphoramidate; Ruelene

2-isopropyl-6-methylpyrimidin-4-yl phosphorothionate; OO-diethyl O-(2-1sopropy!-4methyl-6-pyrimidinyl) phosphorothio

zinon. This is an ingredient of Basudin. (2-chloroethyl) 3-chloro-4-methyl-2-(0xi)-2A-1-benzopyran-7-yl phosphate; 00 -dil (2-chloroethyl (3-chlor

2-(1-methyloctahydroindol-3-yl)ethyl benzilate. The hydrochloride is an ingredient of IBaverin. 6-p-aminophenylph.

The non-proprietary names aro reported to be free from conflict with trade marks registered in Groat Britain and Northorn Ireland, and theso names, or names resembling these names, will not be registered as trade marks for pharruaceutical products or drugs in thoso countrios. Some of the names, other than the chernical narnes, appear. ing in the second column abovo aro registored trade marks. Tho adoption of a non-proprietary namedoes not necessarily imply that the British Votminary Codex Revision Committee recommends the use of tho substance in volorinary medicine or that the substance will be included in the British Voterinary Codex, although if a substance is included, it is intended that the non-propriotary name shall bo the title of the monograph. The British Voterinary Codex Revision Committee has undortaken, at the request of the Association of the British Pharmacoutienl Industry, to provide non-proprietary names for veterinary products, and all requests from manufacturers and other interested persons for the provision of such names should be addressed to the Secretary, British Veterinary Codex Revision Committee, tho Pharmaccutical Society of Great Britain, 17 Bloomsbury Square, London, W.C.1.

\section{Chemicals for the Gardener}

THE second edition of the Ministry of Agriculture, Fisheries and Food practical booklet, Chemicals for the Gardener, has now been published (Pp. iv +35 . London: H.M.S.O., 1965 . 1s. 3d. net). The booklet deals with chemicals which can bo used for the control of gardon pests, diseases and weeds. All the products includod in the booklet have been officially approvod as efficient for tho purposes claimed, and the chemicals contained in them (with the exception of a few compounds which have been in general use for many years) have also been considered by the Government's Advisory Cornmittee on Pesticides and other Toxic Chernicals for thoir possible harmful effoets to humans, farm and domestic animals and wild life (the booklet has the stamp of the Agricultural Chemicals Approval Scheme). Short sections are provided on the safo handling of garden chemicals, the ways and means of obtaining the best results, and hints for choosing the most suitable chemicals. The three main sections deal with 'approved chemicals' for the control of pests and diseases, for the control of weeds, and for fruit setting, rooting, and sealing pruning cuts, etc. All information is clearly laid out undor four columns, and in many cases illustrations are provided. Besides naming the pest/disease and the plant affected, the chemical basis of control is indicated and propriotary products named. A list of firms producing the 'approved chemicals' is appended.

\section{Soils of the West Midlands}

A systematio account of the soils of the counties of Choshire, Shropshire, Staffordshire, Warwickshire, Horefordshire and Worcestershire has been produced by the Soil Survey of Great Britain (Bulletin No. 2: The Soils of the West Midlands. By D. Mackney and O. P. Burnham. Pp. viii + $111+$ map. Harpenden: Rothamsted Experimental Station, 1964. 25s. net). This is a lowland region with only small areas above $800 \mathrm{ft}$., but it is varied in rolief, geology and climate so that thoro is a wido variety of soils representative of most of the major soil groups of Britain. This variation, formerly reflected in the natural vegetation, is to be observed now in such difforent farming systems as upland shoep grazing, dairying, beef production and intensive market garden practice. The report and the map (scale 1 in. to 10 miles) are not intended to prosent detailed information, which is already availablo for many districts in the region and is being steadily extended by the Soil Survey, but a more general picture suitable for agronomists, geographers, ecologists and land planners. Two chapters are devotod to tho processes of soil formation from various parent materials, and tho description of soil profiles and their classification. This is followed by an account of the properties and capabilities of the Wost Midland soils in tho six major groups raw, calcaroous, brown earths, podsolized, gley and organic-with a series of colourod plates to illustrate the profile characteristics. Tho influonce of parent material and relief on the differentiation of soil associations is usefully depicted by block diagrams, and the principal soil sories in tho associations are named and described; further information on all the serries montioned in the text is collected in an appendix. There are three sets of reforoneos and two indexes.

\section{Association of Applied Biologists}

THE following honorary officers of the Association of Applied Biologists were elected for 1965 66 at the recont annual gonoral moeting: President, F. C. Bawden; 